\title{
How is the Education Character Implemented? The Case Study in Indonesian Elementary School
}

\author{
Aningsih' \\ MS Zulela ${ }^{1}$ \\ Amos Neolaka ${ }^{1}$ \\ Vina Iasha ${ }^{2}$ \\ Bramianto Setiawan ${ }^{3 *}$ \\ ${ }^{1}$ Department of Primary Education, Universitas Negeri Jakarta, \\ Jl. R.Mangun Muka Raya No.11, RT.11/RW.14, Rawamangun, \\ Kec. Pulo Gadung, Kota Jakarta Timur, \\ Daerah Khusus Ibukota Jakarta 13220, Indonesia \\ ${ }^{2} S D$ Negeri Pondok Bambu o6, Jl. Pahlawan Revolusi No.Kel, RT.7/RW.4, \\ Pd. Bambu, Kec. Duren Sawit, Kota Jakarta Timur, Daerah \\ Khusus Ibukota Jakarta 13430, Indonesia \\ ${ }^{3}$ Department of Elementary Teacher Education, Universitas PGRI Adi Buana, \\ Jl. Dukuh Menanggal XII, Dukuh Menanggal, Kec. Gayungan, \\ Kota SBY, Jawa Timur 60234, Indonesia \\ ${ }^{*}$ Corresponding Author
}

DOI: https://doi.org/10.36941/jesr-2022-0029

\section{Abstract}

Today, the attitudes and behavior of Indonesian students are declining. Schools as a component of character building have an important task in inculcating morals, ethical values, noble character, and strong and tough characters. This study was conducted to analyze the implementation of character education in Indonesia. The qualitative research using an ethnographic approach was used in this study on the implementation of character education in elementary schools. A total of 115 participants were interviewed at the school, including principals, teachers, extracurricular coaches, parents, and students. Observation, interviews, and documentation were used as the research instrument. From the results of this study, it was found that character education was very much needed in learning. The character education that was implemented in the elementary school sample includes religion; discipline; responsibility; leadership; tolerance; cooperation; love cleanliness; neatness; courtesy; perseverance; bravery; self-confidence; economical; independence; honesty; acceptance diversity; nationalism; Justice; creativity; and reward achievement. This study also described the character education strategies applied in elementary schools, namely, exemplary; habituation; school climate conditioning; integration in learning across all subjects; and integration through extracurricular activities.

Keywords: ethnographic approach; character education; primary school 


\section{Introduction}

Along with the times, education serves an essential and effective role and purpose in the development of human personality and character as a method of developing potential as well as the order of human existence (Setiawan et al., 2017). The creation of a strong national character as the basic capital in constructing a high-level civilization is highlighted as one of the tasks and aims of Indonesian national education (Rachmadtullah et al., 2020). Character education is not a new policy at all because since 2010 character education in schools has become a National Movement (Saidek \& Islami, 2016). Currently, much work needs to be done to ensure that the process of planting and cultivating character values is running and sustainable so that it can respond to the challenges of an increasingly complex era, which range from issues that threaten the nation's integrity and future to global competition.

Currently, many students whose behavior does not know manners and tend not to care about the environment (Abdullah et al., 2019). In addition, various negative behaviors such as the habit of skipping school, cheating on exams, alcohol and drugs, violence and anarchic acts, theft, brawls between students, free sex, sexual deviations, and immoral acts as well as other violations of the law often color the world of Indonesian education. For the sake of the nation's future, situations like these must be handled right now. Character education must be reintroduced as a remedy to this issue. Character education is a system that instills character values in students, including knowledge, individual awareness, determination, and willingness and action to implement values, both towards God, oneself, fellow humans, the environment, and the nation. In any educational organization, character education is a critical need and an important priority (Iasha et al., 2020; Suherman et al., 2019).

Various studies have been conducted in the application of character education. Muttaqin et al. analyzed the implementation of the main values of Strengthening Character Education that the result on the values of religion and nationalism have been very good in the elementary schools (Muttaqin et al., 2018). Puspita et. al. used a poetry appreciation textbook to implementation of character education values (Puspita, 2019). Hermino et al. use contextual learning models to teach character education (Hermino \& Arifin, 2020). On the other hand, Saputro applies a holistic approach to the Implementation of Character Education (Saputro \& Murdiono, 2020). Then Keumala also analyzed the application of character education using gadgets and the internet (Keumala et al., 2019).

With the current state of character decrease in Indonesia, it can be observed from various studies that character education is extremely essential to be grown. Therefore, this study was conducted to analyze the implementation of character education in Indonesia. If previous studies have focused on just one aspect of character education in schools, such as extracurricular activities, school culture, or learning integration, the author of this paper describes the implementation of character education in schools in a broader, more comprehensive, and in-depth manner to fully comprehend the phenome.

\section{Methodology}

\subsection{Research Design}

The qualitative research using an ethnographic approach was used in this study on the implementation of character education in elementary schools. Qualitative research tries to delve further into a person's thoughts or opinions on a certain issue (Glesne, 2016). The investigation was conducted at a Jakarta primary school. The study took place during the odd semester of the 2019-2020 academic year. 


\subsection{Participant}

A total of 115 people were interviewed at the school, including principals, teachers, extracurricular coaches, parents, and students as shown in Table 1.

Table 1: Participant demographics $(n=115)$

\begin{tabular}{|l|l|c|c|}
\hline \multicolumn{2}{|c|}{ Type } & Frequency & Percentage (\%) \\
\hline Gender & Male & 61 & 53 \\
\hline \multirow{3}{*}{ Age } & Female & 54 & 47 \\
\hline & $1-10$ & 75 & 65.2 \\
\hline \multirow{5}{*}{ Education } & $11-20$ & 25 & 21.7 \\
\hline \multirow{5}{*}{ Role } & $21-30$ & 8 & 7 \\
\hline \multirow{5}{*}{} & $31-40$ & 7 & 6.1 \\
\cline { 2 - 4 } & Elementary School & 100 & 87 \\
\cline { 2 - 4 } & Senior High School & 5 & 4.3 \\
\cline { 2 - 4 } & Bachelor Degree & 10 & 8.7 \\
\cline { 2 - 4 } & Principals & 1 & 0.9 \\
\cline { 2 - 4 } & Eeachers & 7 & 6 \\
\cline { 2 - 4 } & Extracurricular coaches & 1 & 0.9 \\
\cline { 2 - 4 } & Parents & 6 & 5.2 \\
\cline { 2 - 4 } & Students & 100 & 87 \\
\hline
\end{tabular}

\subsection{Data Collected and Data Analysis}

Observation, interviews, and documentation were used to gather information. The Spradley model, which includes domain, taxonomy, componential, and theme analysis, was used to examine the data. The researcher was become the primary research instrument and was assisted by observation, interview, and documentation study protocols. The research process was broken down into six steps: 1) Choosing an ethnographic project, 2) asking ethnographic questions, 3) collecting ethnographic data, 4) creating an ethnographic record, 5) analyzing ethnographic data, and 6) producing an ethnography are all steps in the ethnography process. The validation data test was carried out by 1 ) constant observation, growing persistence, triangulation, and reference materials; 2) writing a research report with a full, clear, systematic, and reliable description; 3) conducting a supervisory audit of the whole research process; 4) seek agreement from data sources (Mitchell \& Clark, 2018; Parker, 2004).

\section{Result and Discussion}

Research findings are obtained through observations, interviews, and document analysis related to the research sub-focus that has been determined, namely:

\subsection{Residents' perspectives on character education in schools}

Character education in schools was highly essential to execute, according to the study's findings, since it might mold children's personalities, educate them on how to behave, train discipline, and help them become better and more focused. The existence of this shared understanding of viewpoints implies that the school and parents believe that students not only need to master various sciences but also need to know how to act and behave by societal values and standards. To put it another way, today's education must focus on maximizing children's growth across all dimensions (cognitive, physical, social, emotional, creative, and spiritual) (Darling-Hammond et al., 2020). 
Schools, as a medium for learning, play a significant influence in the character formation of children. The brain, heart, and body of students are developed at this facility to make them smarter, more sensitive, and healthier. The heart and physical health are hoped to become the capital of life in the future, thanks to intelligence. Students may develop the basic potential that every human being possesses to become a person who thinks well, has a decent heart, and behaves well through character education. With intelligence, it is hoped that the heart and physical health can become the capital of life in the future. Through character education, students can develop the basic potential possessed by every human being to become a person who thinks well, has a good heart, and also has good behavior (Lickona, 2009). Furthermore, students may develop and enhance their conduct to survive and adapt to a heterogeneous society.

Character education in schools needs the involvement of all members of the school community, including parents. However, each person must have a prior understanding of the necessity of character education in schools to support its implementation. Character education cannot be done in isolation, such as by parents or schools, but rather involves constructive synergy and teamwork between all aspects. Character education must be carried out over time, gradually and in phases, and it must include a variety of supporting elements such as family, school, community, and government. The four components are jointly responsible for character education. If there is no consistency and harmony between these elements, character education will fail (McGrath, 2018). This aligns with Novianti argument that educational policy should be aimed at achieving moral instruction in the classroom. As stakeholders, parents, teachers, and administrators must all adhere to this policy to encourage children to live lives that reflect these positive values (Novianti, 2017).

\subsection{School-Instilled Character Values}

According to Curren (2017), schools play a critical role in children's character development, particularly if children do not receive character education at home. On the fact that students spend a significant amount of time in school, therefore what is recorded in their memory at that time will influence their personality as they grow older. The sample school has sought to instill character education such as religion, discipline, responsibility, leadership, tolerance, cooperation, love of cleanliness, neatness, politeness, perseverance, courage, self-confidence, frugal, independence, honesty, acceptance diversity, nationalism, justice, creativity, and rewarding achievement. These character values are instilled and developed through various forms of activities at school as shown in table 2.

Table 2: Activities at school in character education adaptation

\begin{tabular}{|c|c|c|}
\hline No. & Character Value & Activity \\
\hline 1 & Religion & $\begin{array}{l}\text { Incorporating school regulations; } \\
\text { Greeting the teacher who greets pupils at the school entrance (for Muslim kids); } \\
\text { Praying before and after studies, meals, and activities; } \\
\text { Dzuhur prayer at a Muslim student congregation; } \\
\text { Every Friday, the Duha prayer and Friday prayers are combined (for Muslim students); } \\
\text { When Muslim students pray in the congregation, there is a devotional session for non-Muslim students } \\
\text { Spiritual rains fall every Thursday } \\
\text { Make a communal sacrifice on Eid al-Adha } \\
\text { Display religious messages such as "Don't forget to pray five times a day." }\end{array}$ \\
\hline 2 & Discipline & $\begin{array}{l}\text { Teacher's example; } \\
\text { Enactment of admission, rest, and return hours by applicable regulations; } \\
\text { Clothing code (uniform) in line with the rules; } \\
\text { Put shoes and learning materials where they belong; } \\
\text { Dispose of garbage in the appropriate location based on the kind of waste; } \\
\text { Do all homework and assignments; } \\
\text { Bring a contact book to school every day; } \\
\text { Engage in all activities in a timely and orderly manner } \\
\text { Bring books according to the lesson plan; } \\
\text { Putting up slogans/slogans } \\
\text { Issuing warnings and sanctions to those who break the regulations. }\end{array}$ \\
\hline
\end{tabular}




\begin{tabular}{|c|c|c|}
\hline No. & Character Value & Activity \\
\hline 3 & Responsibility & $\begin{array}{l}\text { The teacher's example; } \\
\text { Students complete learning assignments; } \\
\text { Students wash their dishes after eating; } \\
\text { Students carry out class picket assignments; } \\
\text { Students attend selected extracurricular activities } \\
\text { Students are appointed to be ceremonial officers; } \\
\text { Students prepare activity equipment; } \\
\text { Slogans/slogans are installed, } \\
\text { Students become librarian }\end{array}$ \\
\hline 4 & Leadership & $\begin{array}{l}\text { Outstanding instructor; } \\
\text { Class president assignment } \\
\text { Ceremonial leader; } \\
\text { Lead prayer; and 5) group leader. }\end{array}$ \\
\hline 5 & Tolerance & $\begin{array}{l}\text { The teacher's example; } \\
\text { Providing the opportunity for each religious believer to worship peacefully; } \\
\text { Mutual respect among religious adherents; } \\
\text { Facilitating religious activities according to the religion embraced. }\end{array}$ \\
\hline 6 & Cooperation & $\begin{array}{l}\text { The teacher's example; } \\
\text { Creating a schedule for class pickets and their assignments; } \\
\text { Group work completing study assignments; } \\
\text { Work together to prepare prayer rooms; } \\
\text { Work together to clean the classroom; } \\
\text { Work together to clean fish ponds; } \\
\text { Cooperate in preparing and returning ceremonial tools; } \\
\text { Cooperate in distributing sacrificial meat. }\end{array}$ \\
\hline 7 & Love of cleanliness & $\begin{array}{l}\text { Example instructors; } \\
\text { The habit of putting trash in its proper place; } \\
\text { The habit of washing hands before eating; } \\
\text { The habit of washing your eating utensils after eating; } \\
\text { The installation of cleanliness slogans and slogans }\end{array}$ \\
\hline 8 & Neatness & $\begin{array}{l}\text { The example of the instructor; } \\
\text { the practice of dressing in a tidy manner; } \\
\text { Place school supplies in a tidy and orderly manner; } \\
\text { During ceremonies, prayers, and scout activities, line up properly. }\end{array}$ \\
\hline 9 & politeness & $\begin{array}{l}\text { The example set by the instructor; } \\
\text { The habit of speaking properly; } \\
\text { When entering the school or teacher's room, it is customary to welcome and shake hands with the teacher. } \\
\text { When passing by others, please excuse yourself; } \\
\text { When others are hungry, offering food to them; } \\
\text { Students who refer to their peers by their parents' names should be reprimanded and punished. } \\
\text { Install phrases such as "Salam, Greet, Smile, Polite and Polite" and "Manners are reflections of the nation's } \\
\text { culture." }\end{array}$ \\
\hline 10 & Perseverance & $\begin{array}{l}\text { Setting an example for students; } \\
\text { assigning learning and training assignments; } \\
\text { Direction so you don't get disheartened quickly and aren't in a rush to work; guidance so you don't get } \\
\text { discouraged easily and aren't in a hurry to work. }\end{array}$ \\
\hline 11 & Courage & $\begin{array}{l}\text { The teacher's example; } \\
\text { Asking students to do assignments in front of the class; } \\
\text { Asking students to be ceremonial officers }\end{array}$ \\
\hline 12 & Self-Confidence & $\begin{array}{l}\text { The teacher's example; } \\
\text { Giving credence to be the class leader, group leader, or ceremony officer; } \\
\text { Praise for students' good attitudes and behavior; } \\
\text { Equal treatment for all students, including children with special needs; } \\
\text { Advising so that students are confident in their religion }\end{array}$ \\
\hline 13 & Frugal & $\begin{array}{l}\text { The teacher's example; } \\
\text { Use of water and electricity as necessary; } \\
\text { Writing on paper is not a waste of time }\end{array}$ \\
\hline 14 & Independence & $\begin{array}{l}\text { The example of the teacher; } \\
\text { Parents are not allowed to wait while students are studying; } \\
\text { Students work on their study assignments; } \\
\text { Students eat and then wash their cutlery; } \\
\text { Prepare and tidy up the school's equipment; } \\
\text { Prepare and tidy up their prayer equipment }\end{array}$ \\
\hline 15 & Honesty & $\begin{array}{l}\text { The teacher's example; } \\
\text { Get students used to telling the truth; } \\
\text { Asking students to admit their mistakes; } \\
\text { Make an honesty box; } \\
\text { Students who lie should be reprimanded and reminded }\end{array}$ \\
\hline
\end{tabular}




\begin{tabular}{|c|c|c|}
\hline No. & Character Value & Activity \\
\hline 16 & Acceptance diversity & $\begin{array}{l}\text { The teacher's example; } \\
\text { The school accepts children with special needs and places them with other students according to their } \\
\text { grade level; } \\
\text { Respects and loves each other even though they are different in various ways (religion, physical condition, } \\
\text { etc.); } \\
\text { Asking students' awareness to share and help their friends with special needs, for example changing seats } \\
\text { during learning activities }\end{array}$ \\
\hline 17 & Nationalism & $\begin{array}{l}\text { Integration in subjects, for example, knowing the map of Indonesia's territory, ethnicity, and customs; } \\
\text { Holding a flag ceremony; } \\
\text { Commemorating independence day }\end{array}$ \\
\hline 18 & Justice & $\begin{array}{l}\text { Exemplary teachers who are not partial, treating all students the same despite different backgrounds } \\
\text { (religion, ethnicity, social and economic status, etc.); } \\
\text { Enforce school rules for all students; } \\
\text { Giving educational punishments to all students who make mistakes; } \\
\text { Assessing students according to their abilities }\end{array}$ \\
\hline 19 & Creativity & $\begin{array}{l}\text { Making handicrafts; } \\
\text { Creating poetry; } \\
\text { Write a personal letter; } \\
\text { Painting and coloring; } \\
\text { Create group games with certain equipment }\end{array}$ \\
\hline 20 & $\begin{array}{l}\text { Rewarding } \\
\text { achievement }\end{array}$ & $\begin{array}{l}\text { The teacher gives praise to students who behave well; } \\
\text { The teacher applauds when students succeed in doing or achieving something; } \\
\text { Posting student work on the classroom board; } \\
\text { Displaying the best work of students on the school wallboard; } \\
\text { Attaching photos and congratulations on the board to students who achieve certain achievements }\end{array}$ \\
\hline
\end{tabular}

Because of the study's limitations, researchers were unable to document all activities and events at schools. However, if referring to Goleman's opinion which states that character education is value education that includes nine interrelated basic values, the school has implemented character education well (Hidayati et al., 2020). Figure 1 shows the documentation of the school's efforts in developing student character values.

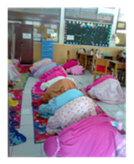

Religion

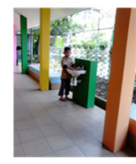

Cleanliness

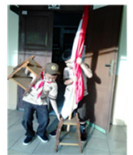

Cooperation

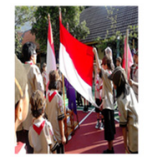

Nasionalism

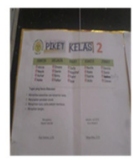

Responsibility

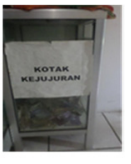

Honesty

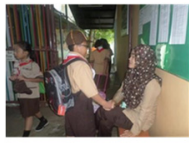

Politeness

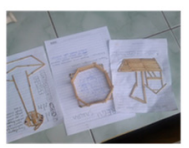

Creativity

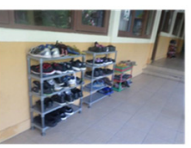

neatness

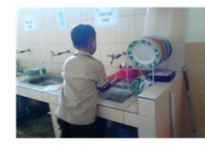

independence

Figure 1: Documentation of the school's efforts in developing student character values

\subsection{Character Teaching Strategies Used in Schools}

According to the findings of the study, schools use a variety of techniques to implement character education, including a) exemplary; b) habituation; c) school atmosphere conditioning, d) integration in the learning process in topics; and e) integration through extracurricular activities. These methods are then deconstructed into actual actions based on what the researchers discovered in the field. The forms of these strategies are relevant to the Fathurrohman and Fitri argument (Fathurrohman, 2013; Fitri, 2012).

Exemplary behavior is the first method used by schools in character education. Everything about a person's words, acts, attitudes, and conduct that may be mimicked or imitated by others is the intended example. Character education can be implemented by providing exemplary behavior to 
students. This is in line with Emily Goodman-findings, Scott's which show that providing examples of appropriate behavior may have a good influence on students (Goodman-Scott et al., 2018). Furthermore, research from Trivette also gives results that giving exemplary behavior in class can affect students' attitudes (Trivette, 2021). According to Laksono (2014), school leaders, teachers, and other education staff must be able to play an active role as cultural ambassadors who can socialize all character values, able to give all students to behave by the values adopted by the school. When a school seeks to implement disciplinary values, for example, all school staff must first be disciplined in carrying out their responsibilities. All school administrators, treasurers, and educators must be able to manage school finances clearly if schools wish to have the principles of honesty and transparency. The point is that no matter how good one's strategy is if it isn't supported by an example, it will fail. As a result, the teacher is viewed as a role model since instructors' attitudes and behaviors have a huge impact on children (Sisson et al., 2017).

The next strategy is habituation. The character development of students can be done by getting used to certain positive behaviors in everyday life. Habituation is a process of forming attitudes and behaviors that are relatively permanent and automatic through a learning process that is repeated, either done together or individually such as praying before learning, praying in congregation, washing hands before and after eating, washing eating utensils alone, put school equipment in their respective lockers, throw garbage in its place, and so on. Character development through this habituation can be done on a scheduled or unscheduled basis both inside and outside the classroom. Attaran suggests that one method of character building in schools is through habituation (Attaran, 2015).

Integrating character education into all courses is the next method for implementing character education. This concept is based on the idea that all instructors should be character educators (Hilyana \& Hakim, 2018). All disciplines are also believed to have a role to play in molding the pupils' noble character. The integration in issue entails the incorporation of values into the content of all topics as well as the development of learning activities that allow the application of values in all activities inside and outside the classroom for all disciplines. Learning activities within the framework of character development of students can use a contextual approach as a learning and teaching concept that helps teachers and students relate the material being taught to real-world situations so that students can make connections between their knowledge and its application in their lives. That way, through contextual learning, students have more comprehensive results not only at the cognitive level (thought), but at the affective level (heart, taste, and intention), as well as psychomotor (sports) (Purba et al., 2020).

Character education in elementary schools may be implemented through a variety of techniques, including school environment conditioning. School should be a comfortable place for students to learn, share hobbies, play, and socialize due to becoming their second home (Gee, 2018). Positive school climate conditioning was carried out based on the findings of the study by creating a safe, clean, beautiful, and comfortable school environment, installing motivational slogans, providing adequate trash cans and dishwashing facilities, establishing school rules, and building good relationships. This is following Werang's findings where explain the collective perception of routine behavior will affect attitudes and behavior at school (Werang, 2018). While Cohen et.al. explained school climate as the quality and character of school life based on the behavior patterns of students, parents, and school personnel experiences about school life that reflect norms, goals, values, interpersonal relationships, teaching and learning practices as well as organizational structure (Pinkus, 2009).

Integration through extracurricular activities is the next approach for implementing character education. Various extracurricular activities organized by school sample include scouts, marching band, futsal, basketball, club science, and dancing. These activities also contribute to the character development and molding of students. Extracurricular activities could expand students' knowledge, regarding the relationship between subjects, channel talents and interests, and complement whole human development. The outcomes of this study back with earlier research that emphasizes the 
importance of extracurricular activities in developing student character. This is consistent with Marini's findings, which show that extracurricular activities might reveal a student's character (Marini, 2017). Figure 2 shows the character education implementation strategies in elementary schools.
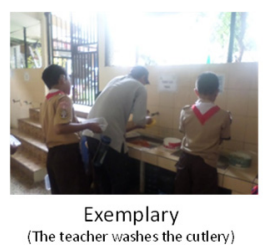

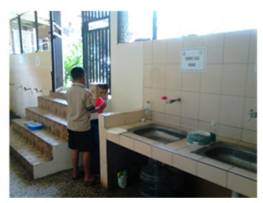

Habituation (Throw garbage in its place)

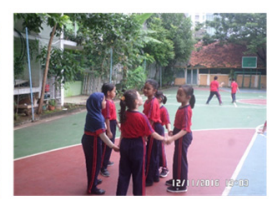

Integration in learning

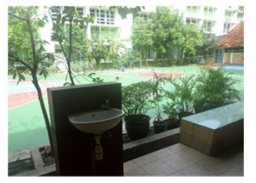

School climate conditioning

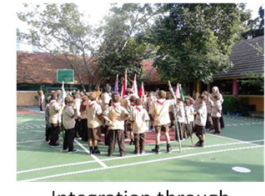

Integration through extracurricular

Figure 2: The Character education implementation strategies in elementary schools

\subsection{Character Education in Primary Schools: Factors That Promote and Hinder Its Implementation}

According to the findings of this study, the good collaboration of all school members, including principals, instructors, and students' parents, is a supportive factor for character education in elementary schools. Education, as a system, is made up of interconnected components, one of which is the educator-non-educator component. All school members must work together to ensure the success of school programs, one of which is character education for pupils, to fulfill the goals of institutional education (Husni, 2020).

Character education in elementary schools is hampered by a lack of character education in the home and a negative response from some parents to the enforcement of school regulations. To address this, schools should improve contact with parents. Because most children spend the majority of their time at home, schools should highlight the importance of character education at home. Parents serve as role models for their children, acting as a mirror (Fuertes et al., 2018). Character education in schools will fail if parents do not support it. Character education in schools will not succeed if it is not supported by parents. All of the school's activities, including the presence of school laws, are geared at building students' character so that they can grow into obedient and decent human beings (Berkowitz et al., 2017).

\section{Conclusion}

This study has been successfully described the implementation of character education in schools with a wider, comprehensive, and in-depth range to comprehensively understand the phenomena that occur in the field. Character values that are instilled in elementary schools include religion; discipline; responsibility; leadership; tolerance; cooperation; love cleanliness; neatness; courtesy; perseverance; bravery; self-confidence; economical; independence; honesty; acceptance diversity; nationalism; Justice; creativity; and reward achievement. This study also describes the character education strategies applied in elementary schools, namely, exemplary; habituation; school climate conditioning; integration in learning across all subjects; and integration through extracurricular activities. In addition, the factors that hinder the implementation of character education in 
elementary schools are the lack of character education in the family environment and the negative response of some parents to the enforcement of school rules.

\section{References}

Abdullah, I., Hudayana, B., Kutanegara, P. M., \& Indiyanto, A. (2019). Beyond school reach: Character education in three schools in Yogyakarta, Indonesia. Journal of Educational and Social Research, 9(3), 145.

Attaran, M. (2015). Moral Education, Habituation, and Divine Assistance in View of Ghazali. Journal of Research on Christian Education, 24(1).

Berkowitz, M. W., Bier, M. C., \& McCauley, B. (2017). Toward a science of character education. Journal of Character Education, 13(1), 33-51.

Curren, R. (2017). Why character education? Impact, 2017(24), 1-44.

Darling-Hammond, L., Flook, L., Cook-Harvey, C., Barron, B., \& Osher, D. (2020). Implications for educational practice of the science of learning and development. Applied Developmental Science, 24(2), 97-140.

Fathurrohman. (2013). Pengembangan Pendidikan Karakter. Refika Aditama.

Fitri, A. Z. (2012). Pendidikan karakter berbasis nilai dan etika di sekolah. Yogyakarta: Ar-Ruzz Media.

Fuertes, M., Sousa, O., Łockiewicz, M., Nunes, C., \& Lino, D. (2018). How different are parents and educators? A comparative study of interactive differences between parents and educators in a collaborative adult-child activity. Plos One, 13(11), e0205991.

Furkan, N. (2014). The Implentation of Character Education through the School Culture in Sma Negeri 1 Dompu and Sma Negeri Kilo Dompu Regency. Journal of Literature and Linguistics, 3, 14-44.

Gee, J. P. (2018). Affinity spaces: How young people live and learn on line and out of school. Phi Delta Kappan, 99(6), 8-13.

Glesne, C. (2016). Becoming qualitative researchers: An introduction. ERIC.

Goodman-Scott, E., Hays, D. G., \& Cholewa, B. E. (2018). "It Takes a Village": A Case Study of Positive Behavioral Interventions and Supports Implementation in an Exemplary Urban Middle School. The Urban Review, 50(1), 97-122.

Hermino, A., \& Arifin, I. (2020). Contextual Character Education for Students in the Senior High School. European Journal of Educational Research, 9(3), 1009-1023.

Hidayati, N. A., Waluyo, H. J., \& Winarni, R. (2020). Exploring the Implementation of Local Wisdom-Based Character Education among Indonesian Higher Education Students. International Journal of Instruction, 13(2), 179-198.

Hilyana, F. S., \& Hakim, M. M. (2018). Integrating Character Education on Physics Courses with Schoology Based E-learning. Journal of Information Technology Education: Research, 17(1), 577-593.

Husni, H. (2020). Character education in Indonesia: a historical outlook. Educational Review: International Journal, 17(1), 147-162.

Iasha, V., Al Ghozali, M. I., Supena, A., Wahyudiana, E., Setiawan, B., \& Auliaty, Y. (2020). The Traditional Games Effect on Improving Students Working Memory Capacity in Primary Schools. Proceedings of the 4 th International Conference on Learning Innovation and Quality Education, 1-5.

Keumala, M., Yoestara, M., \& Putri, Z. (2019). The Impacts Of Gadget And Internet On The Implementation Of Character Education On Early Childhood. International Conference on Early Childhood Education, 313-325.

Lickona, T. (2009). Educating for character: How our schools can teach respect and responsibility. Bantam.

Marini, A. (2017). Building students' characters through extracurricular activities. Advances in Social Science, Education and Humanities Research, 66(1), 266-268.

McGrath, R. (2018). What is character education. Journal of Character Education, 14, 23-35.

Mitchell, K. M., \& Clark, A. M. (2018). Five steps to writing more engaging qualitative research. SAGE Publications Sage CA: Los Angeles, CA.

Muttaqin, M. F., Raharjo, T. J., \& Masturi, M. (2018). The Implementation Main Values of Character Education Reinforcement in Elementary School. Journal of Primary Education, 7(1), 103-112.

Novianti, N. (2017). Teaching Character Education to College Students Using Bildungsromans. International Journal of Instruction, $10(4), 255^{-272 .}$

Parker, L. (2004). Qualitative research. Routledge.

Pinkus, B. L. M. (2009). Moving Beyond AYP: High School Performance Indicators. Alliance for Excellent Education.

Purba, S. K., Angin, R. B. P., \& Yus, A. (2020). The Development of Teaching Materials of Bhineka Tunggal Ika by Integrating Character Education Using Contextual Learning. Budapest International Research and Critics in Linguistics and Education (BirLE) Journal, 3(4), 2221-2232. 
Puspita, O. W. (2019). The Effectiveness of Poetry Appreciation Textbook for Character Education Implementation at Higher Education. International Journal of Instruction, 12(1), 685-700.

Rachmadtullah, R., Yustitia, V., Setiawan, B., Mahya Fanny, A., Pramulia, P., Susiloningsih, W., Tur Rosidah, C., Prastyo, D., \& Ardhian, T. (2020). The Challenge Of Elementary School Teachers To Encounter Superior Generation In The 4.0 Industrial Revolution: Study Literature. International Journal of Scientific $\mathcal{E}$ Technology Research, 9(4), 1879-1882. www.ijstr.org

Saidek, A. R., \& Islami, R. (2016). Character Issues: Reality Character Problems and Solutions through Education in Indonesia. Journal of Education and Practice, 7(17), 158-165.

Saputro, J. D., \& Murdiono, M. (2020). Implementation of character education through a holistic approach to senior high school students. International Journal of Multicultural and Multireligious Understanding, 7(11), $460-470$.

Setiawan, B., Septianto, R., Suhendra, D., \& Iskandar, F. (2017). Measurement of 3-axis magnetic fields induced by current wires using a smartphone in magnetostatics experiments. Physics Education, 52(6), o65011. https://doi.org/10.1088/1361-6552/aa83e3

Sisson, S. B., Smith, C. L., \& Cheney, M. (2017). Big impact on small children: Child-care providers' perceptions of their role in early childhood healthy lifestyle behaviours. Child Care in Practice, 23(2), 162-180.

Suherman, A., Supriyadi, T., \& Cukarso, S. H. I. (2019). Strengthening national character education through physical education: An action research in Indonesia. International Journal of Learning, Teaching and Educational Research, 18(11), 125-153.

Trivette, M. B. (2021). Exemplary Classroom Management Practices Among the Elementary Teachers of Bicol University Integrated Laboratory School. Bicol University $R \mathcal{E} D$ Journal, 22(1).

Werang, B. R. (2018). The effect of workload, individual characteristics, and school climate on teachers' emotional exhaustion in elementary schools of Papua. Cakrawala Pendidikan, 37(3), 457-469. 